Article

\title{
Messages about Antibiotic Resistance in Different Newspaper Genres
}

\author{
Parastou Donyai *, Sochima Okafor, Rachel Virgo, Krina Amin and Marwa Nasr \\ Reading School of Pharmacy, University of Reading, PO Box 226, Whiteknights, Reading RG6 6AP, UK; \\ E-Mails: sochima.okafor@yahoo.co.uk (S.O.); rachel_virgo@hotmail.com (R.V.); \\ krina_88@hotmail.com (K.A.); marwanasr_89@yahoo.com (M.N.) \\ * Author to whom correspondence should be addressed; E-Mail: p.donyai@reading.ac.uk; \\ Tel.: +44-118-378-4704; Fax: +44-118-378-4703.
}

Received: 23 August 2013 / Accepted: 29 September 2013 /

Published: 21 October 2013

\begin{abstract}
Poorer people are more likely to use antibiotics; inappropriate antibiotic use causes resistance, and health campaigns attempt to change behaviour through education. However, fuelled by the media, the public think antibiotic resistance is outside their control. Differences in the attribution of blame for antibiotic resistance in two genres of UK newspapers, targeting distinct socioeconomic groups, were examined using a mixed methods approach. Firstly, depiction of blame was categorised as either external to the lay public (outside their control) or internal (lay person accountable) and subjected to a chi-square test. Secondly, using critical discourse analysis, we examined the portrayal of the main agents through newspaper language. Data from 597 articles (307 broadsheets) analysed revealed a significant association between newspaper genre and attribution of blame for antibiotic resistance. While both newspaper types blamed antibiotic resistance predominantly on factors external to the lay public, broadsheets were more likely to acknowledge internal factors than tabloids. Tabloids provided a more skewed representation, exposing readers to inaccurate explanations about antibiotic resistance. They highlighted ineptitude in health professionals, victimising patients and blaming others, while broadsheets used less emotive language. Pharmacists should take special care to communicate the importance of appropriate antibiotic use against this backdrop of distortion.
\end{abstract}

Keywords: antibiotic resistance; risk perception; attribution theory; newspapers; consumer health information; linguistics 


\section{Introduction}

Antibiotics kill or inhibit the growth of pathogenic bacteria, but less than one hundred years since their discovery, antibiotic resistance is now a palpable threat to public health worldwide [1]. Resistance describes a clinical phenomenon whereby a previously effective antibiotic no longer works because the target pathogen has developed a defence against it, for example through mutations during replication or by acquiring genes encoding resistance from other bacteria [2]. While a range of factors contribute to the development of resistance, it is generally accepted that using antibiotics promotes the emergence and spread of resistance and that once developed resistance can be transmitted from person to person [2,3]. Antibiotic resistance is not a disease in itself but it can result in higher morbidity, mortality, extra hospital and outpatient costs and loses in productivity [4]. A range of antibiotic-resistant bacteria have been identified [5].

The World Health Organisation has defined health professional and patient factors associated with antibiotic misuse or resistance and potential interventions for dealing with these [6]. Antibiotic resistance in the community has become a particular problem in recent times [7] and this makes recommendations relating to patients and the general public especially pertinent. People should be educated about appropriate and inappropriate uses of antibiotics including when to expect an antibiotic prescription, the importance of adherence to prescribed regimen as well as the need to avoid self-medication [6]. Risk factors for the emergence of antibiotic resistance in the community are continually mapped [8]. However, antibiotic prescribing and usage remain a particular risk and initiatives such as the European Antibiotic Awareness Day (EAAD), 18 November, launched in 2008 attempt to encourage responsible use through health promotion [9]. Table 1 combines the factors contributing to antibiotics misuse and/or resistance according to the WHO and EAAD. In the UK, video campaigns too attempt to steer patients away from expecting antibiotic prescriptions for colds and flu [10]. In the US, the Centre for Disease Control and Prevention also runs various campaigns aimed at addressing the issue of antibacterial resistance in different settings [11].

Table 1. Factors contributing to antibiotic misuse and/or resistance according to the WHO and European Antibiotic Awareness Day (EAAD).

\begin{tabular}{ll}
\hline Health professionals: prescribers and dispensers & Patients \\
\hline WHO & WHO \\
Lack of knowledge & Self-medication \\
Inadequate diagnosis & Poor adherence \\
Incorrect drug selection & High need (poor underlying health) \\
Incorrect prescribing (dose/duration/route) & Misinformation/inappropriate beliefs \\
Prescribing in response to patient pressure & Poverty-associated under treatment \\
Fear of litigation & An "expensive is better" myth \\
Financial gain & Expectation of treatment \\
Response to promotional pressure & Response to advertising \\
EAAD & EAAD \\
Unnecessary prescription of antibiotics & Not completing a course of as prescribed \\
Unsuitable use of broad-spectrum antibiotics & Skipping doses of antibiotics \\
Wrong selection of antibiotics & Not taking antibiotics at regular intervals \\
Inappropriate duration or dose of antibiotics & Saving some for later \\
\hline
\end{tabular}


Certainly there is evidence to show a correlation between poor understanding of antibiotics and inappropriate usage and a tendency to demand antibiotics [8]. In addition, those more knowledgeable about antibiotics are more likely to finish a course of antibiotics [11]. What is more, antibiotic prescribing is highest amongst those with lower educational levels and those from lower socioeconomic classes [12]. These findings all give credence to health campaigns attempting to change people's behaviour. Yet, it is also known from years of research in the behavioural field that a multitude of factors influence behaviour at the level of the individual patient and that educational campaigns are not always effective at changing behaviours because of the complexity of decision-making processes [13]. Educational messages about antibiotic usage do not always translate into the desired behaviours [14].

Research has shown that the lay public do not recognise their own contribution towards antibiotic resistance, viewing the matter instead as outside of their own control and blaming "dirty hospitals", unhygienic nurses, the government and hospital managers, doctors overprescribing antibiotics and the "other irresponsible people" who misuse antibiotics $[3,10,15,16]$. The way in which causation or blame is attributed in relation to health is important because it has been shown to correlate with behaviour. Those who recognise their own internal contribution to events exhibit higher levels of adherence to treatment, engagement in self-management, health awareness, health service utilisation and making positive health behavioural changes [17-19]. In contrast, attributing cause to the environment and external factors outside of one's control correlate with lower levels of engagement in self-management and poorer health behavioural decisions [20,21]. Thus potentially the impact of health campaigns seeking positive behavioural change such those promoting antibiotic awareness could be undermined by whether people recognise their own capacity to influence the problem of antibiotic resistance. This is akin to a vicious circle and warrants an examination of potential differences in how people form their lay opinions.

While health campaigns rely on the media to act as a source of information and learning, lay media, newspapers especially can be a more potent influence on people. In fact participants in qualitative studies have cited newspapers as a primary source of information about their knowledge of antibiotic resistance [22]. Other studies too have investigated the newspapers' power to influence and form the lay public's health perceptions and behaviour at an international level [23-28]. How antibiotic resistance is reported in newspapers has been investigated previously in the context of MRSA in the UK with researchers mainly employing discourse analysis to catalogue the portrayal of the problem. For example, Crawford et al. [29] found newspapers depicted doctors and hospitals as perpetrators of crimes of omission by not cleaning hands or wards. Chan et al. [30] described the use of "the dirty hospital" a powerful metaphor for political games by journalists and politicians alike. The latter is especially pertinent since in an empirical study no correlation could be demonstrated between general hospital cleanliness and MRSA rates. Nonetheless, Boyce et al. [31] examining the reported causes of MRSA in both quality (broadsheets) and popular (tabloid) newspapers in the UK, also reported hospital cleanliness and cleaners as the most cited reason for the problem (36\%). But they also identified a host of other spurious causes and worryingly found antibiotic over-prescribing cited in only $5.6 \%$ of reports and pressure to over-prescribe in only $0.4 \%$. In terms of solutions, again cleaner wards were cited in most cases (38\%) but reducing drug use was cited in only $2.3 \%$ of the articles examined. Thus certainly for MRSA it is not science that appears to influence media coverage of MRSA but a motivation for exaggerated reporting. 
However, to group together findings from all newspapers in this way might be considered a generalisation. Tabloid and broadsheet address a socioeconomic divide with the former catering mostly for those in lower socioeconomic groups [32]. In the UK, broadsheet newspapers typically report on politics, world news, economics and similar stories, whereas tabloids rather prefer "lighter" news, focusing more on personal stories, celebrity news, popular entertainment and scandal [33-36]. Tabloids are described as sensationalistic, employing simplistic and "everyday" informal speech while broadsheets adopt a more academic, formal speech. Tabloid reporting style has been criticised for distorting facts and providing an inaccurate picture for readers and tabloid readers have been accused of suffering from media malaise, where a lack of informative discourse limits political knowledge. On the other hand, broadsheet readers are thought to engage more in refined political debate because they are "better educated" and better informed. We imagined tabloid newspapers were more likely to report the problem of antibiotic resistance as external to their readers and a "fault" of others such as government, hospitals, policy makers and the like, with broadsheets on the other hand, providing a more balanced representation.

How do the different genres of newspaper in the UK attribute blame for the problem of antibiotic resistance? We asked this research question since tabloids are read mostly by those in lower socioeconomic groups reported to have the highest antibiotic usage [12]. Could it be that those in lower socioeconomic groups are further disadvantaged by distorted reporting? This is an important question for health professionals such as pharmacists who try to tackle misplaced beliefs in their everyday practice and have been shown to reach people across the socioeconomic divide [37]. The topic is also important for policy makers and we sought specifically to look at newspaper reporting from 2008 onwards, a year that saw the launch of the European Antibiotic Awareness Day. Our research hypothesis was that the genre of newspaper would affect the attribution of blame for antibiotic resistance. We sought to examine through the use of content and discourse analysis the way in which blame for antibiotic resistance was depicted through the use of language because the expression of words can impact on people's sense of power and control [38].

\section{Experimental Section}

\subsection{Design}

A two-factor design was used. The independent variable was newspaper genre with the two conditions, tabloid and broadsheet. The dependent variable was the attribution of blame for antibiotic resistance with the two conditions, internal (lay person accountable) or external (outside of lay person's control). Attributions were coded as internal if they blamed the problem of antibiotic resistance on patients' antibiotic use/other related behaviours, travellers, health tourists and any other persons considered "lay" in relation to healthcare. Attributions were coded as external attributions if they blamed the problem of antibiotic resistance on doctors, nurses, hospital managers, cleaners, pharmaceutical companies, and the government. Bacterial mechanisms such as evolution, rapid cell division were also categorized as external. 


\subsection{Materials}

Based on circulation figures [39], the top four UK broadsheets (The Daily Telegraph; The Independent; The Guardian; The Times) and the top four UK tabloid newspapers (The Mirror; The Sun; The Daily Mail; The Daily Express) were selected for study. A total of 877 articles were first retrieved. Once collected, data was entered onto the SPSS v.15 software [40] for Windows for statistical analysis.

\subsection{Procedure}

Four researchers (SO, KA, MN and RV) jointly collected, coded and analysed the data. The internet search function available on each newspaper's website was employed for retrieving relevant articles. The European Antibiotic Awareness Day was launched in 2008 and this study was undertaken in Spring 2011. Therefore, newspaper articles were retrieved for the three years since the launch of the EAAD, from Jan 2008 to December 2010 inclusive. The search terms antibiotic resistance, antibiotic use, bacterial resistance, MRSA and superbug were employed consistently through the search exercise. Each article retrieved was read and examined to confirm that it included adequate reference to antibiotics and importantly who was to blame for antibiotic resistance. Articles were excluded if they fell outside of the timeframe, were letters to editors, obituaries and other such items not written by a journalist or contributing author, or mentioned antibiotic resistance only in passing or did not attribute blame for the problem.

To enable coding, the main body of each article was pasted into a separate Word document in no specific order, removing any reference to the newspaper source or genre. Two raters "blinded" to article source then independently coded each article as either internal or external in terms of the attribution of blame for antibiotic resistance. The task of coding was apportioned between the researchers SO, KA, $\mathrm{MN}$ and RV. A separate pilot assessed inter-rater reliability resulting in a free-marginal kappa of 0.79 , indicating sufficient consistency between the raters. Nonetheless, for the main study, all codes were compared for consistency and where necessary agreement reached through a consensus discussion. Where disagreement remained, the article was excluded from analysis. Once coded, the articles were "un-blinded" to enable compilation of the data into a contingency table.

In addition to examining articles for attribution of blame, we used discourse analysis [41] in an attempt to uncover the way in which central actors or agents had been presented through the use of language, style, structure of speech and writing. The fundamental approach was to consider text not as a means with which ideas were being communicated neutrally or objectively but as an instrument for the social construction of (different versions of) reality. The researchers read and re-read the articles focusing on linguistics, the choice and tone of words, symbolic descriptions, and rhetoric, focusing particularly on the devices used to depict the "perpetrators" (those to blame) and "innocents".

\section{Results and Discussion}

\subsection{Quantitative Analysis}

A total of 877 articles were retrieved, 280 met one or more exclusion criteria, therefore a total of 597 articles (307 broadsheet) were included in the analysis (see Table 2). The majority of articles were 
written in 2008 (55\%), with 25\% written in 2009 and 20\% written in 2010. The Daily Mail (34\%) and The Sun (32\%) accounted for more of the tabloid articles than The Daily Express (20\%) and The Mirror (14\%). The Daily Telegraph (38\%) and The Guardian (31\%) accounted for more broadsheet articles than The Times (21\%) and The Independent (10\%).

Table 2. Contingency table showing attribution of blame and newspaper genre.

\begin{tabular}{llll}
\hline & Internal attribution of blame & External attribution of blame & Total \\
\hline Tabloid newspaper & 31 & 259 & 290 \\
Broadsheet newspaper & 56 & 251 & 307 \\
Total & 87 & 510 & 597 \\
\hline
\end{tabular}

The data were analysed using a chi-square test $\left(\chi^{2}=6.831, \mathrm{df}=1, p=0.009\right.$, Cramer's $\left.\mathrm{V}=0.107\right)$. The analysis revealed a statistically significant association so the null hypothesis was rejected in favour of the research hypothesis that there is an association between newspaper genre and attribution of blame for antibiotic resistance. While both newspaper genres blamed antibiotic resistance predominantly on factors external to the lay public, broadsheets were more likely to blame internal factors than tabloids.

\subsection{Discourse Analysis}

While the ranges of topics covered by broadsheet and tabloid articles were similar, there were distinctions in the reporting styles of these newspapers. The way in which main actors/agents, namely hospitals, healthcare professionals and powerful others, patients and bacteria, were presented by the different newspaper genres is summarised in Table 3. Quotes from newspapers illustrate these themes in Table 4.

Tabloids frequently employed symbolic imagery, with depictions of gross negligence within the "dirty hospital". The mention of "victims" at the mercy of the merciless "powerful others" heightened the role of the reader's (i.e., patient's) insignificance to problem of antibiotic resistance. With broadsheets though, infection control was sometimes discussed as a solution to the problem without an accusatory tone towards the hospital and its workers. Also broadsheets were more impartial compared to tabloids which directly connected hospital managers with increasing antibiotic resistance-related deaths. Both genre of newspapers employed statistics within their headlines to arguably portray a scandal. The use of numbers can suggest an impending epidemic, with the possible result of heightening the reader's perception of their risk.

Importantly, the link between misuse of antibiotics and the occurrence of antibiotic resistance was hardly ever mentioned. The one exception was where "expert" or "world authority" opinions were included, advising prudent antibiotic use by a doctor or another authority:

"Always finish your course of medication" ("Mistakes with medicine you shouldn't make" Mirror, 18 August 2008).

“Keep taking the pills” (Mirror, 1 October 2009). 
Table 3. Categorisation of main findings according to newspapers depiction of actors/agents in the discourse.

\begin{tabular}{|c|c|c|}
\hline $\begin{array}{l}\text { Depiction of } \\
\text { actors/agents }\end{array}$ & Tabloid newspapers & Broadsheet newspapers \\
\hline Hospitals & $\begin{array}{l}\text { Symbolic images/metaphors of dirt } \\
\text { and filth; use of statistics to } \\
\text { emphasize impact of dirty hospitals. }\end{array}$ & $\begin{array}{l}\text { Less provocative, fewer metaphors; } \\
\text { attribute blame to hospital (un)cleanliness } \\
\text { but can also portray hospitals as actively } \\
\text { tackling antibiotic resistance. }\end{array}$ \\
\hline $\begin{array}{l}\text { Healthcare } \\
\text { professionals } \\
\text { and powerful others }\end{array}$ & $\begin{array}{l}\text { Convey mistrust of managers-"inept", } \\
\text { "nincompoops". Articles invoke sense } \\
\text { of injustice from "powerful others" at } \\
\text { the expense of patients. }\end{array}$ & $\begin{array}{l}\text { Convey mistrust, but more objective; } \\
\text { more implicit that explicit in attributing } \\
\text { blame to management and government. }\end{array}$ \\
\hline Patients & $\begin{array}{l}\text { Portrayed as "victims", suffering and } \\
\text { defenceless; Use personal narratives, } \\
\text { with children, "war heroes" and the } \\
\text { elderly particularly reported. }\end{array}$ & No personal narratives \\
\hline Bacteria & $\begin{array}{l}\text { Anthropomorphized-"killer bugs", } \\
\text { "mega bugs", "unfussy"; use of } \\
\text { "warfare" metaphor to evoke fear, } \\
\text { e.g., they are "unbeatable" in our } \\
\text { battle against them-able to } \\
\text { "wriggle...out of tight spaces...to } \\
\text { evade the drugs we bombard them } \\
\text { with". "unfussy with who they mate } \\
\text { with...to strengthen their defences". }\end{array}$ & $\begin{array}{l}\text { Also used the warfare metaphor. } \\
\text { describing a "war against superbugs", } \\
\text { heightening the battle against bacteria. } \\
\text { Less anthropomorphic otherwise. }\end{array}$ \\
\hline Scientists & \multicolumn{2}{|c|}{$\begin{array}{l}\text { Fight against bacteria was reported by both genres to be fought by medical } \\
\text { authority, scientists in particular. Hopes of scientists close to a "cure" as they } \\
\text { "shed light on how to kill MRSA" were raised, asking if "science can save us..?" } \\
\text { Responsibility of halting antibiotic resistance was assigned to the "boffins", the } \\
\text { knowledgeable others. }\end{array}$} \\
\hline
\end{tabular}

Table 4. Quotes from newspapers illustrating the ways in which hospitals, health professionals and powerful others as well as patients were portrayed in tabloid and broadsheet newspaper genres.

\begin{tabular}{lll}
\hline $\begin{array}{l}\text { Depiction of } \\
\text { actors/agents }\end{array}$ & Tabloid newspapers & Broadsheet newspapers \\
\hline Hospitals & "...Dirty mops...next to a filthy food trolley" & "Initiatives such as the "deep \\
& ("National Filth Service: Report reveals wards & clean”...have had the desired effect" \\
& overrun with rats" Daily Mail. 6 August 2008). & ("MRSA rates fall-but other superbugs \\
& "...dust and dirt everywhere" ("Superbug in a & increase". The Times. 18 July 2008). \\
& filthy hospital killed our lovely girl”. & "Comprehensive infection control \\
& $\begin{array}{l}\text { Daily Express. 17 May 2008). } \\
\text { "Viewpoint: How dare we let these dirty hospitals }\end{array}$ & $\begin{array}{l}\text { advice... provided..." ("A new superbug } \\
\text { foun Britain is a major concern". }\end{array}$ \\
& kill 8,000 a year?" (Daily Mail, 17 June 2008). & The Daily Telegraph. 8 August 2009). \\
\hline
\end{tabular}


Table 4. Cont.

\begin{tabular}{|c|c|c|}
\hline $\begin{array}{c}\text { Healthcare } \\
\text { professionals } \\
\text { and powerful } \\
\text { others }\end{array}$ & $\begin{array}{l}\text { "...justice laughs in the face of the victims as it } \\
\text { rewards those who least deserve it" ("A } \\
\text { sickening injustice". Daily Mail. } 24 \text { June 2010). } \\
\text { "criminal negligence...dangerous nincompoops" } \\
\text { ("Op (sic.) went well...pity patient is in } \\
\text { morgue". Daily Express. } 10 \text { February 2008). }\end{array}$ & $\begin{array}{l}\text { "no evidence that the (MRSA) deaths } \\
\text { amounted to manslaughter" ("Superbug } \\
\text { hospital escapes criminal charges". } \\
\text { The Guardian, } 30 \text { July 2008). } \\
\text { "Doctors under fire: Handing out } \\
\text { antibiotics like Smarties?" ("Briefing: } \\
\text { Antibiotic resistance". The Times, } 20 \\
\text { November 2008). }\end{array}$ \\
\hline Patients & $\begin{array}{l}\text { "Patients had to drink from flower vases" } \\
\text { ("Scandal-hit Stafford Hospital "covered up" } 13 \\
\text { new superbug cases". The Mirror, } 1 \text { May 2009). } \\
\text { "...patients...unwashed for...a MONTH by } \\
\text { uncaring nurses..." ("Fury over report into } \\
\text { NHS horror", The Sun, } 25 \text { February 2010). } \\
\text { "...ninety-year old...so frail...absolutely } \\
\text { distraught" ("Superbug horror for pensioner". } \\
\text { The Mirror, } 24 \text { February, 2009). }\end{array}$ & No personal narratives. \\
\hline
\end{tabular}

\subsection{Discussion}

In the UK, both newspaper genres blamed antibiotic resistance predominantly on factors external to the lay public but broadsheet newspapers were more likely to acknowledge internal factors compared to tabloids. Importantly, on the whole, both genres of newspapers hardly ever explained the relation between antibiotics misuse and antibiotic resistance. There was a difference in the way tabloids and broadsheets depicted the problem, with tabloids more likely to portray a defenceless public falling victim to external factors outside of their control. Using symbolic imagery to paint suffering, tabloids were inclined to highlight ineptitude in health professionals, victimising patients by stressing their defencelessness. Resistant bacteria were portrayed as invincible. Broadsheets were less critical of the health professions and used more sophisticated, less emotive language, backed up by more in-depth factual content. Both genre of newspaper used statistics to conjure up an impending epidemic. In a small number of instances doctors writing gave advice about appropriate antibiotic use.

Easton et al. [16] found the public were aware of MRSA but lacked knowledge about it. When Washer et al. [42] examined the social representation of MRSA, they too found a strong tendency for blame to be apportioned to "the other" with sensationalist coverage conjuring an image of doom, while hospital staff's incompetence helped spread a condition that would mark the end of a "golden age of medicine". Before the relationship between germ and disease was established scientifically in the 19th century, the mechanism for transmission of diseases was unclear. When Washer et al. [22] compared people's beliefs with newspaper stories, they found stories about dirty and badly managed hospitals and the management culture of the NHS resonated well with the general public indicating a pre-scientific understanding of germs, contagion and blame. Brooks et al. [3] found the causes of, and responsibility for, antibiotic resistance were attributed to external rather than personal factors with patients perceiving that solutions were outside of their control. The results here provide further support in relation to the social representation of antibiotic resistance in UK newspapers and its potential impact on the public's 
perception of blame and control. In addition, our results highlight a difference between the two different genres of newspaper, which suggests those in lower socioeconomic groups reading tabloids are more likely to be presented with inaccurate explanations about the spread of antibiotic resistance.

To the authors' knowledge there is yet no published study using attribution of blame to examine modern-day differences in portrayals of antibiotic resistance across different newspaper genres. We found the predominant message being delivered to the public via newspapers at odds with the aims of the European Antibiotic Awareness Day campaign which attempts to inculcate a sense of personal control over the issue of antibiotic resistance. The findings could mean that tabloid readers may not only come to believe that they have no control over the issue of resistance, but also feel victimised as a community for the "mistakes" of powerful others consequently, re-iterating blame onto doctors, cleaners, the government and the like. Creating misconceptions and sensationalism appeared to take precedence over unambiguous health messages in tabloid newspapers. Because higher levels of antibiotic prescribing occur in practices serving more deprived communities [12], it is thought-provoking that the different newspaper genres might be encouraging health inequalities in their readership through their misaligned coverage of causal attribution and knowledge about antibiotic resistance.

This study focussed on the top 8 newspapers in the UK. Most of the existing research on antibiotic resistance and its representation in the British media has also focused solely on MRSA yet there are other resistant strains of bacteria that perhaps the public need to be made aware of in order to broaden their knowledge of antibiotic resistance. Future studies could specifically investigate the portrayal of resistant bacteria other than MRSA in the print and other media. Future studies could investigate how knowledge of the attributions of blame regarding antibiotic resistance projected by the media in different socioeconomic groups can help shape and further refine material for more tailored public awareness campaigns.

There are implications for practice in terms of public health and pharmacy. First, policy makers should take note of the potent power of tabloid media in particular and the fact that health campaigns could well be undermined by public opinion shaped by the everyday representations of antibiotic resistance as outside of people's control. Second, while also taking note of underlying differences in people's knowledge base, health professionals such as pharmacist should take special care to explain the importance of appropriate use, as a real means with which patients, especially those from lower socioeconomic classes can help restrain the problem of antibiotic resistance. Perhaps even, health professionals and others could try to work with newspapers to influence reporting.

\section{Conclusions}

In conclusion, the results of the study reported here offer support for a theory linking newspaper genre with attribution of blame for antibiotic resistance. Future research conducted in this area could verify the findings in other countries and offer better ways of integrating the message from European Antibiotic Awareness Day within the printed press.

\section{Conflicts of Interest}

The authors declare no conflict of interest. 


\section{References}

1. Hojgard, S. Antibiotic resistance-why is the problem so difficult to solve? Infect. Ecol. Epidemiol. 2012, doi:10.3402/iee.v2i0.18165.

2. Alanis, A.J. Resistance to antibiotics: Are we in the post-antibiotic era? Arch. Med. Res. 2005, 36, 697-705.

3. Brooks, L.; Shaw, A.; Sharp, D.; Hay, A.D. Towards a better understanding of patients' perspectives of antibiotic resistance and MRSA: A qualitative study. Fam. Pract. 2008, 25, 341-348.

4. French, G.L. The continuing crisis in antibiotic resistance. Int. J. Antimicrob. Agents 2010, 36, S3-S7.

5. Gerlich, M.G.; Möller, A.; Schäfer, C.; Strohbach, A.K.; Krafczyk-Korth, J.; Hoffmann, W. Epidemiology of multi-resistant organisms - challenges to a regional data management system. GMS Krankenhhyg Interdiszip. 2011, 6, 1-6, (in German).

6. World Health Organization. Communicable Disease Surveillance and Response. In Containing Antimicrobial Resistance: Review of the Literature and Report of a WHO Workshop on the Development of a Global Strategy for the Containment of Antimicrobial Resistance. World Health Organization: Geneva, Switzerland, 1999.

7. Maki, D.G.; Safdar, N.; Ebert, S.C. Prevalence, consequences, and solutions. Pharmacotherapy 2007, 27, 121S-125S.

8. Aiello, A.E.; Larson, E. Antibacterial cleaning and hygiene products as an emerging risk factor for antibiotic resistance in the community. Lancet Infect. Dis. 2003, 3, 501-506.

9. McNulty, C.A.; Johnson, A.P. The European Antibiotic Awareness Day. J. Antimicrob. Chemother. 2008, 62, 853-854.

10. Newton, J.T.; Constable, D.; Senior, V. Patients' perceptions of methicillin-resistant Staphylococcus aureus and source isolation: A qualitative analysis of source-isolated patients. J. Hosp. Infect. 2001, 48, 275-280.

11. McNulty, C.A.; Boyle, P.; Nichols, T.; Clappison, P.; Davey, P. Don't wear me out - the public's knowledge of and attitudes to antibiotic use. J. Antimicrob. Chemother. 2007, 59, 727-738.

12. Wilson, R.P.; Hatcher, J.; Barton, S.; Walley, T. The association of some practice characteristics with antibiotic prescribing. Pharmacoepidem. Dr. S. 1999, 8, 15-21.

13. Donyai, P. Social and Cognitive Pharmacy: Theory and Case Studies; Pharmaceutical Press: London, UK, 2012.

14. Stockley, J.M. European antibiotic awareness day 2010: Why doesn't promoting antibiotic awareness always work? J. Infect. 2010, 61, 361-363.

15. Hawkings, N.J.; Wood, F.; Butler, C.C. Public attitudes towards bacterial resistance: A qualitative study. J. Antimicrob. Chemother. 2007, 59, 1155-1160.

16. Easton, P.M.; Marwick, C.A.; Williams, F.L.; Stringer, K.; McCowan, C.; Davey, P.; Nathwani, D. A survey on public knowledge and perceptions of methicillin-resistant Staphylococcus aureus. J. Antimicrob. Chemother. 2009, 63, 209-214.

17. Bucks, R.S.; Hawkins, K.; Skinner, T.C.; Horn, S.; Seddon, P.; Horne, R. Adherence to treatment in adolescents with cystic fibrosis: The role of illness perceptions and treatment beliefs. J. Pediatr. Psychol. 2009, 34, 893-902. 
18. Przybylski, M. Health locus of control theory in diabetes: A worthwhile approach in managing diabetic foot ulcers? J. Wound Care 2010, 19, 228-233.

19. Audulv, A.; Asplund, K.; Norbergh, K.G. Who's in charge? The role of responsibility attribution in self-management among people with chronic illness. Patient Educ. Counsel. 2010, 81, 94-100.

20. Locher, J.L.; Burgio, K.L.; Goode, P.S.; Roth, D.L.; Rodriguez, E. Effects of age and causal attribution to aging on health-related behaviors associated with urinary incontinence in older women. Gerontologist 2002, 42, 515-521.

21. Runions, S.; Arnaert, A.; Sourial, R. Causal attributions and health behavior choices among stroke and transient ischemic attack survivors. J. Neurosci. Nurs. 2006, 38, 288-295.

22. Washer, P.; Joffe, H.; Solberg, C. Audience readings of media messages about MRSA. J. Hosp. Infect. 2008, 70, 42-47.

23. Calloway, C.; Jorgensen, C.M.; Saraiya, M.; Tsui, J. A content analysis of news coverage of the HPV vaccine by US newspapers, January 2002-June 2005. J. Wom. Health 2006, 15, 803-809.

24. Carducci, A.; Alfani, S.; Sassi, M.; Cinini, A.; Calamusa, A. Mass media health information: quantitative and qualitative analysis of daily press coverage and its relation with public perceptions. Patient Educ. Counsel. 2011, 82, 475-478.

25. Matamoros, D.J.; Axelsson, R.; Strid, J. How do newspapers deal with health in Sweden? A descriptive study. Patient Educ. Counsel. 2007, 67, 78-83.

26. McDonnell, D.D.; Lee, H.J.; Kim, Y.B.; Kazinets, G.; Moskowitz, J.M. Cancer coverage in a mainstream and Korean American online newspaper: lessons for community intervention. Patient Educ. Counsel. 2008, 71, 388-395.

27. Mizuno, Y.; Narimatsu, H.; Kishi, Y.; Kodama, Y.; Murashige, N.; Yuji, K.; Matsumura, T.; Kami, M. Structural problems of medical news reports in newspapers: A verification of news reports on an incident of mass nosocomial Serratia infection. J. Infect. Chemother. 2010, 16, 107-112.

28. O'Hara, S.K.; Smith, K.C. Presentation of eating disorders in the news media: What are the implications for patient diagnosis and treatment? Patient Educ. Counsel. 2007, 68, 43-51.

29. Crawford, P.; Brown, B.; Nerlich, B.; Koteyko, N. The 'moral careers' of microbes and the rise of the matrons: An analysis of UK national press coverage of methicillin-resistant Staphylococcus aureus (MRSA) 1995-2006. Health Risk Soc. 2008, 10, 331-347.

30. Chan, P.; Dipper, A.; Kelsey, P.; Harrison, J. Newspaper reporting of meticillin-resistant Staphylococcus aureus and 'the dirty hospital'. J. Hosp. Infect. 2010, 75, 318-322.

31. Boyce, T.; Murray, E.; Holmes, A. What are the drivers of the UK media coverage of meticillin-resistant Staphylococcus aureus, the inter-relationships and relative influences? J. Hosp. Infect. 2009, 73, 400-407.

32. Readership Estimates-Newspapers and Supplements: July 2011-June 2012. Available online: http://www.nrs.co.uk/choose-trends/ (accessed on 15 October 2013)

33. Fritz, E. Audience Orientation in News Stories: A Comparison between The Guardian and The Sun; GRIN Verlag OHG: Munich, Germany, 2009.

34. Barnes, R.C.; Earnshaw, S. Mental illness in British newspapers: (Or my girlfriend is a rover metro). Psychiatr. Bull. 1993, 17, 673-674.

35. Newton, J. Mass media effects: Mobilization or media malaise? Br. J. Polit. Sci. 1999, 29, 577-599.

36. Seale, C. Media and Health; Sage Publications Ltd.: London, UK, 2003. 
37. Donyai, P.; van den Berg, M. Coronary heart disease risk screening: The community pharmacy Healthy Heart Assessment Service. Pharm. World Sci. 2009, 31, 643-647.

38. Van den Berg, M.; Donyai, P. How was patient empowerment portrayed in information leaflets describing the community pharmacy Medicines Use Review service in the UK? Patient Educ. Counsel. 2010, 80, 274-276.

39. Circulations ABC. Newspaper Circulation Figures, 2013. Available online: http://www.abc.org.uk/ (accessed on 23 August 2013).

40. SPSS v.15 Software. SPSS Inc: Chicago, IL, USA, 2006.

41. Potter, J.; Wetherell, M. Social Psychology and Discourse: Beyond Attitudes and Behaviour; Sage Publications Ltd.: London, UK, 1987.

42. Washer, P.; Joffe, H. The "hospital superbug": Social representations of MRSA. Soc. Sci. Med. 2006, 63, 2141-2152.

(C) 2013 by the authors; licensee MDPI, Basel, Switzerland. This article is an open access article distributed under the terms and conditions of the Creative Commons Attribution license (http://creativecommons.org/licenses/by/3.0/). 